\title{
A Huge Ovarian Cyst in a Middle-Aged Iranian Female
}

\author{
Mohammad Kazem Moslemi $^{\mathrm{a}}$ Zahra Yazdani $^{\mathrm{b}}$ \\ aDepartment of Urology, Kamkar Hospital, School of Medicine, Qom Medical \\ Sciences University, and ${ }^{b}$ Department of Gynecology, Valiasr Hospital, Qom, Iran
}

\section{Key Words}

Mucinous cystadenoma · Abdominal masses - Abdominal distention - Ovarian cysts . Ovarian tumors

\begin{abstract}
A 38-year-old Iranian woman was found to have a huge ovarian cystic mass. Her presenting symptom was vague abdominal pain and severe abdominal distention. She underwent laparotomy and after surgical removal, the mass was found to be mucinous cystadenoma on histology.
\end{abstract}

\section{Introduction}

Ovarian cysts rarely grow immense. Ultrasonography scanning permits early detection and appropriate treatment. Occasionally, ovarian cysts reach enormous dimensions without raising any symptom. A few cases of giant ovarian cysts have been sporadically reported in the literature [1-4].

\section{Case Presentation}

The patient is a 38-year-old Iranian married and multiparous female who presented at our surgical department with a gradually increasing abdominal swelling first noticed 1 year ago. The swelling was accompanied by vague abdominal pain since 6 months before admission. There was no history of colicky pain, fainting attacks, vomiting or other gastrointestinal attacks. She had no previous history of any illnesses, allergies or operations. She is P5L4D4, has been married for 20 years and had normal regular menses. Based on sonographic examinations, a huge abdominal cystic mass that occupied all of the abdomen and pelvic cavity was noted. On general examination, she was slim and undernourished. She weighed $52 \mathrm{~kg}$. Pallor was present and vital signs were normal. There was no icterus, edema, or lymphadenopathy. Abdominal examination showed general distension (fig. 1). The liver and spleen were not palpable. Percussion note was dull all over the abdomen with positive fluid thrill. Abdominal bowel sounds were heard normally. Vaginal examination showed only cystocele grade 1. Hemoglobin was $11 \mathrm{~g} / \mathrm{dl}$, and other hematological or biochemical serum tests were normal. Chest X-ray was normal. 


\begin{tabular}{c|l|l|l}
$\begin{array}{c}\text { Case Reports in } \\
\text { Oncology }\end{array}$ & $\begin{array}{l}\text { Case Rep Oncol 2010;3:165-170 } \\
\text { D01: } 10.1159 / 000314525\end{array}$ & Published online: May 7, 2010 & $\begin{array}{l}\odot \text { 2010 S. Karger AG, Basel } \\
\text { ISSN 1662-6575 } \\
\text { www.karger.com/cro }\end{array}$ \\
\hline
\end{tabular}

Abdominal ultrasonography was suggestive of a huge abdominal cystic mass. Uterus was normal and seen separate from the mass. Abdominal organs were compressed by the mass, and a mild right hydronephrosis was seen. Abdominopelvic computerized tomography (CT) findings were consistent with a large abdominopelvic cystic mass (ig. 2). The patient underwent laparotomy with a low midline incision, extending up to the umbilicus. After opening the layers, a large tense, smooth surfaced cystic mass was noted (fig. 3). The mass was so large that it could not be excised without a large abdominal incision, so we drained the intra-cystic fluid with creation of a small hole in the mass, and 6 liters of clear fluid were drained, until we could excise the cyst with its remaining fluid (fig. 4). The cyst measured $65 \times 45 \times 35 \mathrm{~cm}$, extended up to the undersurface of the diaphragm, and totally weighted 12 $\mathrm{kg}$. The mass originated from the right ovarian region. So we excised the cyst with the ipsilateral fallopian tube and ovary. The right ovary was included in the mass. The right fallopian tube was adherent to the surface of the cyst. There was no free fluid in the abdomen. Pathology confirmed serous cystadenoma of the ovary. The postoperative period was uneventful and the patient was discharged on the fourth day after operation. After 3 months, in order to decrease the possibility of recurrence and malignant transformation, total abdominal hysterectomy with left salpingo-oophorectomy was performed. The patient has been regularly followed up for a period of 1 year, and she has remained healthy with no recurrence of the disease.

Written informed consent was obtained from the patient for publication of this case report.

\section{Discussion}

Mucinous cystadenomas (MCAs) of the ovary are known for their potential to grow to massive proportions and are often incidentally diagnosed. They are typically benign tumors accounting for $15 \%$ of ovarian neoplasms and up to $80 \%$ of all mucinous tumors [5]. Ovarian MCAs are characteristically unilateral, only 5\% presenting bilaterally, and the peak incidence occurs among women who are between 30 and 50 years of age [6]. Ovarian neoplasms may be divided according to original cell types into 3 main groups: epithelial, stromal, and germ cell. Taken as a group, the epithelial tumors are by far the most common type. The single most common benign ovarian neoplasm is the benign cystic teratoma; however, according to some studies, it is serous cystadenoma. The most common types of epithelial neoplasms encountered were benign cystadenoma, of which $75 \%$ were serous cystadenomas and $25 \%$ were MCAs. Mucinous tumors of the ovary occur principally in middle adult life and are extremely rare prior to menarche. The histopathological groups of mucinous tumors are described as follows: (1) MCA, (2) mucinous tumor of uncertain malignant potential (borderline), and (3) mucinous carcinoma [7]. MCA appears as a large cystic mass, is often multiloculate, and contains sticky gelatinous fluid. Microscopically, the tumor consists of cystic spaces lined by tall columnar epithelium with mucinous differentiation. In general, ovarian MCAs tend to present with abdominal distention. The vast majority of mucinous tumors are benign (75\%), 10\% borderline, and 15\% carcinomas [8]. One of the major differential diagnoses of ovarian cysts are omental cysts. Omental cysts occur in all age groups, but most often they present in children and young adults [9]. These masses may be simple or multiple, may be huge, and simulating ascites. Ascites is another entity that must be included in the list of differential diagnoses. Other diagnoses may be mesenteric cysts, cysts arising from retroperitoneal structures like pancreatic pseudocysts, urinary retention, bladder diverticulum, hydronephrosis, cystic lymphangiomas, choledochal cysts, splenic cysts, multicystic dysplastic kidney, gastrointestinal duplication cysts and large uterine tumors [10-16]. Management of ovarian cysts depends on the patient's age, the size and structure of the cyst and menopausal status [17]. Surgical management of cysts is by laparotomic or laparoscopic cyst excision or cystectomy with oophorectomy. 


\begin{tabular}{r|l|l|l}
$\begin{array}{r}\text { Case Reports in } \\
\text { Oncology }\end{array}$ & $\begin{array}{l}\text { Case Rep Oncol 2010;3:165-170 } \\
\text { D0I: } 10.1159 / 000314525\end{array}$ & Published online: May 7, 2010 & $\begin{array}{l}\text { O 2010 S. Karger AG, Basel } \\
\text { ISSN 1662-6575 } \\
\text { www.karger.com/cro }\end{array}$ \\
\hline
\end{tabular}

\section{Conclusion}

There has been no report of a mass of this weight in our institution before, and it is one of the largest tumors reported in Iran in the literature.

Fig. 1. Generalized distension of the abdomen is evident.

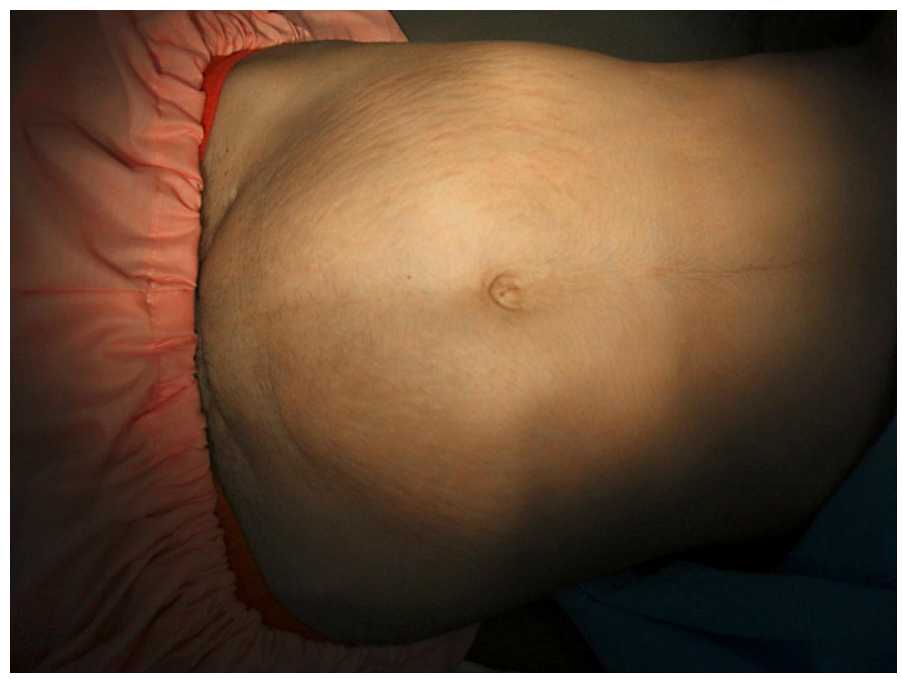




\begin{tabular}{r|l|l|l}
$\begin{array}{r}\text { Case Reports in } \\
\text { Oncology }\end{array}$ & $\begin{array}{l}\text { Case Rep Oncol 2010;3:165-170 } \\
\text { D0I: 10.1159/000314525 }\end{array}$ & Published online: May 7, 2010 & $\begin{array}{l}\text { O 2010 S. Karger AG, Basel } \\
\text { ISSN 1662-6575 } \\
\text { www.karger.com/cro }\end{array}$ \\
\hline
\end{tabular}

Fig. 2. Abdominopelvic CT scan of the patient.

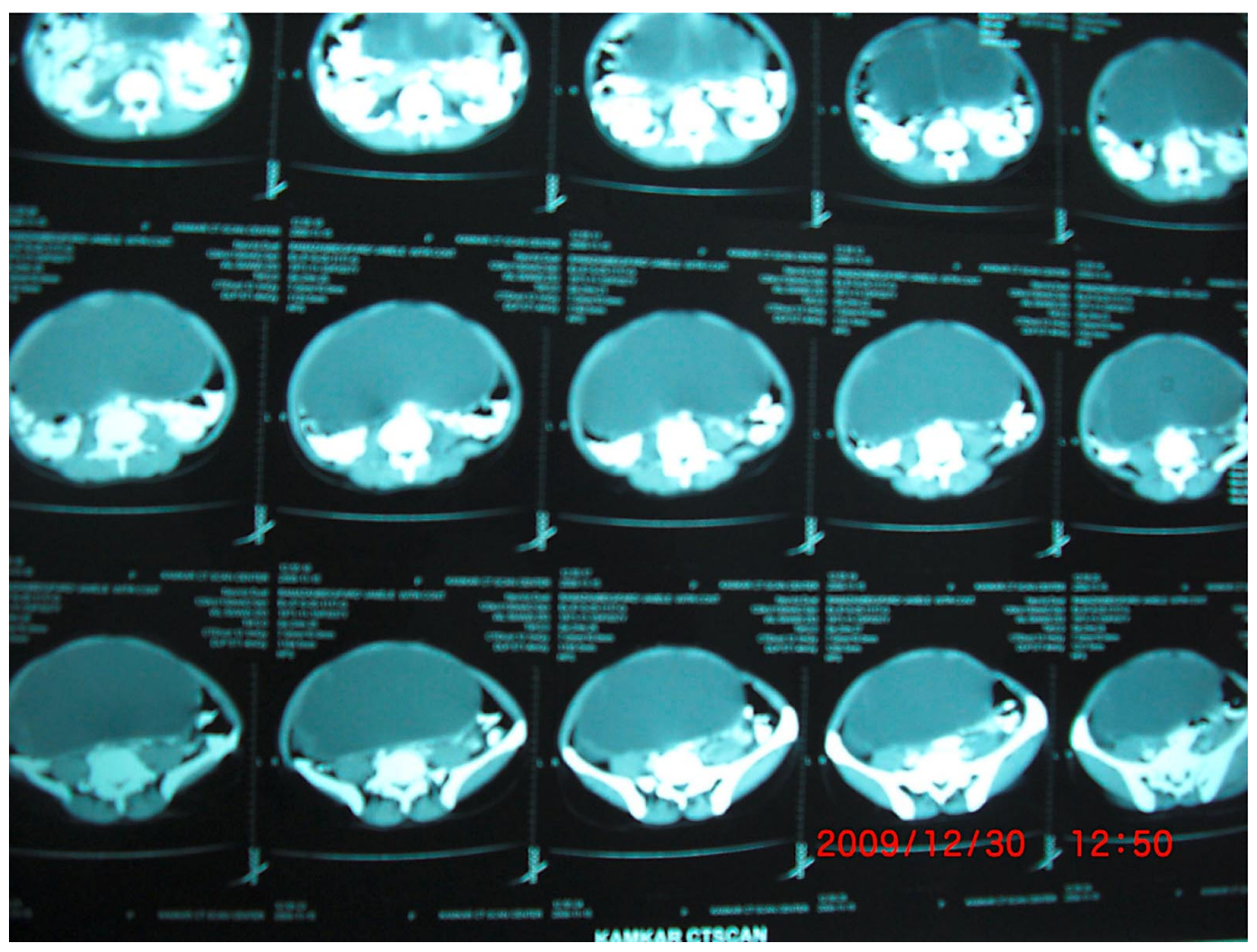

Fig. 3. The mass just after opening of the abdominal layers.

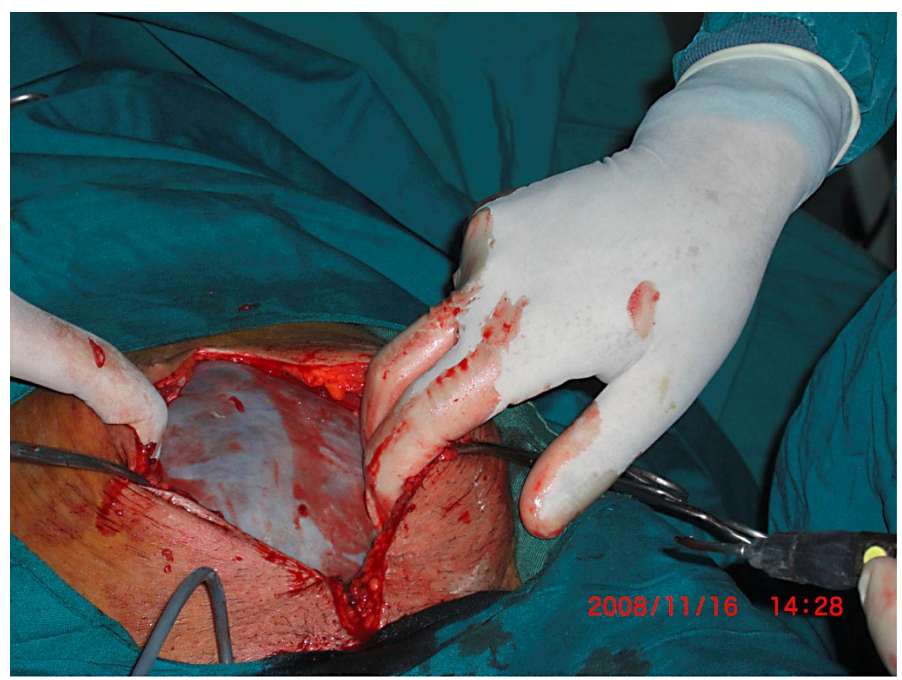


Fig. 4. The excised mass after draining 6 liters of fluid.

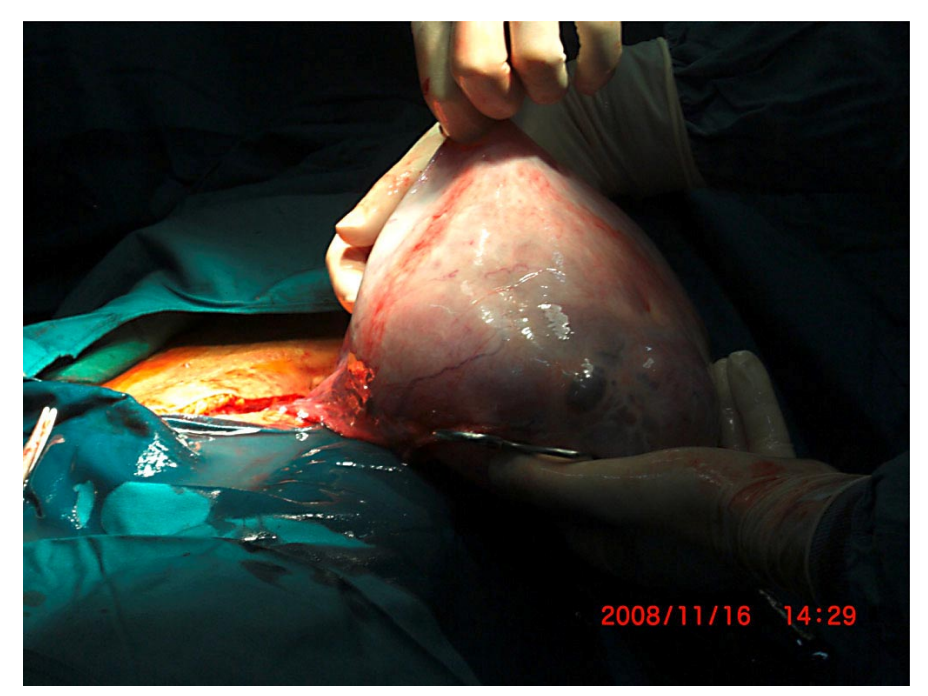




\section{References}

1 Menahem S, Shvartzman P: Giant ovarian cyst mimicking ascites. J Fam Pract 1994;39:479-481.

-2 Lombardo L, Babando GM: Giant ovarian cyst mimicking ascites. Gastrointest Endoc 1986;32:245-246.

-3 Farinetti A, Butazzi A, Tazzioli G, Saviano L, Saviano M: Giant ovarian cyst. A case weighing $23 \mathrm{~kg}$. Literature review. Minerva Chir 2003;58:261-265.

4 Hunter DJ: Management of massive ovarian cyst. Obstet Gynecol 1980;56:254255.

5 Malakan AD, Singh-Braich P, Dudrick SJ: Mucinous cystadenoma of the ovary presenting as unilateral lower extremity edema. Conn Med 2009;73:517-519.

6 Hart WR: Mucinous tumors of the ovary: a review. Int J Gynecol Pathol 2005;24:4-25.

7 Sri Paran T, Mortell A, Devaney D: Mucinous cystadenoma of the ovary in perimenarchal girls. Pediatr Surg Int 2006;22:224.

8 Rodriguez IM, Part J: Mucinous tumors of the ovary. A clinicopathologic analysis of 75 borderline tumors (of intestinal type) and carcinomas. Am J Surg Pathol 2002;26:139.

9 Walker AR, Putham TC: Omental, mesenteric and retroperitoneal cyst. A clinical study of 33 new cases. Ann Surg 1973;178:13-19.

10 Semchyshyn S, Strickler RC, Gerulath AH: Giant ovarian cyst in a dwarf. Can J Surg 1977;20:153-155.

11 Zanini P, Cavalca A, Benatti E, Drei B: Benign giant ovarian cystadenoma. Description of a clinical case. Minerva Ginecol 1996;48:215-219.

12 Rattan KN, Budhiraja S, Pandit SK, Yadav RK: Huge omental cyst mimicking ascites. Indian J Pediatr 1996;63:707-708.

13 Zamir D, Yuchtman M, Amar M, Shoemo U, Weiner P: Giant mesenteric cyst mimicking ascites. Harefuah 1996;130:683-684.

$\checkmark 14$ Chen SS: A large retroperitoneal cyst mimicking ascites. A case report. J Reprod Med 1979;22:261-263.

15 Grobe JL, Kozarek RA, Sanowski RA, Earnest DL: 'Pseudo-ascites' associated with giant ovarian cysts and elevated cystic fluid amylase. Am J Gastroenterol 1983;78:421-424.

16 Wootton-Gorges SL, Thomas KB, Harned RK, Wu SR, Stein-Wexler R, Strain JD: Giant cystic abdominal masses in children. Pediatr Radiol 2005;35:1277-1288.

17 Ishioka S, Sagae S, Ito E, Kudo R: Ultrastructural study of benign, low-malignant potential (LMP), and malignant ovarian tumors. Med Electron Microsc 2004;37:37-44. 